\title{
General Aspects of Primary Cancer Prevention
}

\author{
Miodrag N. Krstic Dragana D. Mijac Dusan D. Popovic \\ Aleksandra Pavlovic Markovic Tomica Milosavljević \\ Clinic for Gastroenterology and Hepatology, Clinical Canter of Serbia, School of Medicine, University of Belgrade, \\ Belgrade, Serbia
}

\section{Keywords}

Cancer prevention · Aspirin · Digestive oncology

\begin{abstract}
Background: Cancer is the second leading cause of death worldwide next to cardiovascular diseases. Despite the advancement in screening, early diagnosis, and development in treatment technology in last several decades, cancer incidence overall, particularly that of gastrointestinal (GI) cancers, is far from being controlled, and is expected to increase worldwide. Summary: Although numerous preclinical and population-based clinical studies have already made important progress in restraining the overall cancer incidence and mortality, the full potential of preventive strategy is still far from being realized, and remains at an early stage. There are several major challenges regarding this issue, and one of the crucial challenges is to maintain the balance between risks and benefits. As a result of past investments, primary prevention nowadays include the integration of various activities such as lifestyle changes to reduce risk, screening to detect early lesions, vaccines and preventive therapies aimed to actively interrupt the carcinogenic pathway. Long-term aspirin
\end{abstract}

\section{KARGER}

(c) 2019 S. Karger AG, Basel

E-Mail karger@karger.com

www.karger.com/ddi use seems to have the largest potential effect on the general population on cancer incidence and mortality overall, especially GI cancers. Helicobacter pylori eradication reduces the risk for gastric cancer and is advocated regardless of the symptoms and stage of disease. Metformin and statins are promising in cancer prevention in patients with type 2 diabetes. Vitamin D supplementation is promising in the prevention of colorectal adenoma recurrence. Key Message: However, additional studies are warranted to establish the potential of various agents and to identify more specific and highly targeted new agents for chemoprevention in digestive oncology.

(c) 2019 S. Karger AG, Basel

\section{Introduction}

Despite the advancement in screening, early diagnosis, and progress in treatment technology, cancer still remains the second leading cause of death worldwide, next to cardiovascular diseases (CVDs) [1]. According to the global burden of disease study, in 2015, there were 17.5 million cancer cases worldwide and over 8.8 million deaths due 
to cancer [2]. Between 2005 and 2015, cancer incidence increased by $33 \%$ at the global level, while most of this increase can be explained by an aging population and population growth. Thus, in 2015, colorectal cancer (CRC) was among the 3 most common incident cancers in both sexes, while the leading causes of deaths from cancer were stomach and liver cancer in men and CRC in women [1]. According to current data from the National cancer Institute for cancer statistics in the United States, gastrointestinal (GI) cancers are in the top 10 cancers in the world. Additionally, the top 3 causes of death from GI disease are CRC, followed by pancreatic and liver cancers $[3,4]$. Thus, GI cancer incidence is far from being controlled, and is expected to increase worldwide, even in countries with the advanced health care systems [1]. Consequently, chemoprevention appears to be the frontline strategy in fighting against cancers already, and is ranked as a prime importance to reduce the global burden of cancer.

\section{Key Problems in Chemoprevention}

The term "chemoprevention" was first introduced by Sporm in 1976, and refers to the use of nontoxic chemical substances, of either natural or synthetic origin to delay, retard, or reverse the carcinogenesis process [5]. Since then, efforts have been made to search for potential chemopreventive agents. Thus, numerous preclinical and population-based clinical studies have already made important progress in restraining cancer incidence and mortality [6-11]. However, the full potential of chemopreventive strategy is still far from being realized, and remains at an early stage. There are several major challenges regarding this issue, and one of the crucial challenges is to maintain the balance between risks and benefits. Indeed, cancer preventive therapies have been primarily intended for use in healthy individuals who may never actually develop cancer. Furthermore, targeting high-risk individuals for specific therapies to prevent cancer is essential to achieve a favorable benefit-risk ratio, and to avoid associated adverse effects or ineffective treatments $[10,11]$. On the other hand, the nature of cancer still remains very complex and not fully understood, while potential biomarkers of susceptibility to specific cancer are either lacking or are not available for routine use in everyday clinical practice. In addition, specific factors that predict response to treatments are still poorly understood. For these reasons, further studies with a large number of participants are required to evaluate the potential new agents. These trials warranted long follow-up period, since preventive effects often take a long time to become visible, as early stages of the carcinogenesis are targeted. Therefore, the focus of digestive oncology is to determine the individual risk of developing disease, to help improve patient's health, and to predict the future development of disease. Moreover, the new concept of personalized medicine has been adopted also in digestive oncology. This concept represents treat to target concept, tailoring medicine to patient preferences, with the potential to identify treatments with the optimal response and highest safety in order to ensure better patient care. From this perspective, we will discuss here some of the most important challenges in primary GI cancer prevention and chemoprevention as well. The most common chemopreventive agents and potential effective preventive treatments in GI oncology are shown in Table 1.

\section{Results}

\section{Treatments with Preliminary Evidence of}

\section{Cancer Prevention}

Today primary prevention is the strategy that comprises several preventive measures, such as lifestyle changes to reduce risk, screening to detect early lesions and preventive therapies aimed to actively interrupt the carcinogenic pathway - chemoprevention [10].

\section{Diet and Lifestyle}

GI cancers include cancers of the esophagus, stomach, intestine, colorectum, liver, and pancreas. A vast majority of the GI cancers have etiologic link with dietary and lifestyle factors, commonly named "Western lifestyle," of which point is critical basis for prevention. Thus, in the last 30 years, many studies have shown that GI cancers, particularly CRC can be prevented by changing dietary habit and lifestyle [12-19]. Regarding lifestyle factors, there is convincing evidence, that abstinence from alcohol and smoking, physical activity and prevention of obesity can each have a positive effect on GI cancer prevention. A large cohort study of 43,479 participants showed that reasonable physical activity, specifically aerobic exercise of any intensity, is a common protective factor for GI cancers [18]. Many studies confirmed the presence of a protective effect of aerobic exercise to digestive tract cancers, in particular, for CRC [20-23]. Moreover, the association between CRC and high consumption of red meat, processed food, high fat dairy products, refined sugars and starches, is well known and has been shown in several studies [13-17]. Although many studies have provided some protective effect of 
Table 1. Agents for treatment of precancerous lesions or cancer risk reduction

\begin{tabular}{|c|c|c|c|c|c|}
\hline Study & Treatment offered/cancer site & \multicolumn{2}{|c|}{ Number of cases/controls } & Design & Main results \\
\hline \multicolumn{6}{|l|}{ Aspirin and celecoxib trials } \\
\hline $\begin{array}{l}\text { Flossmann and Rothwell [37], } \\
\text { Lancet, } 2007\end{array}$ & Aspirin $300-1,200 \mathrm{mg} / \mathrm{CRC}$ & 5,061 & 2,527 & Meta analyses BDAT; UK-TIA & $\begin{array}{l}\text { Aspirin use for } 5 \text { years is effective in } \\
\text { primary prevention }\end{array}$ \\
\hline $\begin{array}{l}\text { Rothwell et al. [48], } \\
\text { Lancet, } 2010\end{array}$ & Aspirin $75-1,200 \mathrm{mg} / \mathrm{CRC}$ & 8,282 & 5,751 & $\begin{array}{l}\text { Meta analyses BDAT; UK-TIA; } \\
\text { SALT; TPT }\end{array}$ & $\begin{array}{l}\text { Aspirin reduced long-term incidence } \\
\text { and mortality }\end{array}$ \\
\hline $\begin{array}{l}\text { Rothwell et al. [54], } \\
\text { Lancet, } 2011\end{array}$ & Aspirin/all cancers & 14,035 & 11,535 & $\begin{array}{l}\text { Meta analyses BDAT; TPT; } \\
\text { UK-TIA; ETDRS;SAPAT; } \\
\text { JPAD; POPADAD; AAA }\end{array}$ & $\begin{array}{l}\text { Aspirin reduced deaths due to } \\
\text { esophagealadenoCa, pancreatic, CRC, } \\
\text { brain, lung adenoCa, stomach and } \\
\text { prostate cancers. Benefits increased with } \\
\text { the duration of treatment }\end{array}$ \\
\hline $\begin{array}{l}\text { Cao et al. [55], } \\
\text { JAMA Oncol, } 2015\end{array}$ & Aspirin/all cancers & 135,965 & & $\begin{array}{l}\text { Two prospective cohort studies: } \\
\text { Nurses Health Study; Health } \\
\text { Professionals Follow-up Study }\end{array}$ & $\begin{array}{l}\text { Aspirin modestly reduced the incidence } \\
\text { of overall cancer, especially for GI } \\
\text { cancers }\end{array}$ \\
\hline $\begin{array}{l}\text { Ye et al. [56], } \\
\text { PLoS One, } 2013\end{array}$ & Aspirin/gastric cancer & 6,868 & & Meta analyses; 15 studies & $\begin{array}{l}\text { Long-term ( } 4 \text { years) aspirin useis } \\
\text { associated with reduction in the risk of } \\
\text { gastric cancer }\end{array}$ \\
\hline $\begin{array}{l}\text { Steinbah et al. [26], } \\
\text { N Engl J Med, } 2000\end{array}$ & Celecoxib/FAP & 62 & 15 & RTC & $\begin{array}{l}\text { Celecoxib leads to a significant } \\
\text { reduction in the number of polyps in } \\
\text { patients with FAP }\end{array}$ \\
\hline $\begin{array}{l}\text { Spence et al. [59], } \\
\text { Gastroenterology, } 2018\end{array}$ & $\begin{array}{l}\text { Aspirin/esophageal and } \\
\text { gastric cancer }\end{array}$ & $\begin{array}{l}4,654 \\
\text { esophageal }\end{array}$ & 3,240 gastric & Two population-based studies & $\begin{array}{l}\text { Aspirin was not associated with } \\
\text { increased survival }\end{array}$ \\
\hline \multicolumn{6}{|l|}{ H.pylorierdiction therapy } \\
\hline $\begin{array}{l}\text { Nakamura et al. [62], } \\
\text { Gut } 2012\end{array}$ & Gastric MALT lymphoma & $\begin{array}{l}420 \text { gastric } \\
\text { MALT }\end{array}$ & & Multicenter cohort study & $\begin{array}{l}\text { Excellent long-term outcome of gastric } \\
\text { MALT lymphoma after H. pylori } \\
\text { eradication }\end{array}$ \\
\hline $\begin{array}{l}\text { Ford et al. [64], } \\
\text { BMJ } 2014\end{array}$ & Gastric cancer & 3,294 & 3,203 & Meta-analysis of RCT & $\begin{array}{l}\text { Eradication therapy for } \mathrm{H} \text {. pylori } \\
\text { reduces the incidence of gastric cancer }\end{array}$ \\
\hline $\begin{array}{l}\text { Choi et al. [65], } \\
\text { NEJM, } 2018\end{array}$ & Metachronous gastric cancer & $\begin{array}{l}470 \text { early } \\
\text { gastric cancer }\end{array}$ & & RCT & $\begin{array}{l}\text { H. pylori treatment prevents } \\
\text { metachronous cancer in patients with } \\
\text { early gastric cancer }\end{array}$ \\
\hline
\end{tabular}

\begin{tabular}{|c|c|c|c|c|c|}
\hline \multicolumn{6}{|l|}{ Metformin } \\
\hline $\begin{array}{l}\text { Evans et al. [71], } \\
\text { BMJ, } 2005\end{array}$ & Cancer risk in T2DM & 983 & 1,846 & Pilot case-control study & $\begin{array}{l}\text { Metformin may reduce the risk of cancer } \\
\text { in patients with T2DM }\end{array}$ \\
\hline $\begin{array}{l}\text { Currie et al. [72], } \\
\text { Diabetologia, } 2009\end{array}$ & Cancer risk in T2DM & $\begin{array}{l}62,809 \text { cases } \\
\text { with T2DM }\end{array}$ & & Cohort study & $\begin{array}{l}\text { Metformin reduces risk of CRC and } \\
\text { pancreas cancer }\end{array}$ \\
\hline $\begin{array}{l}\text { DeCensi et al. [73], } \\
\text { Cancer Prev Res, } 2010\end{array}$ & Cancer risk in T2DM & $\begin{array}{l}4,042 \text { cancer } \\
\text { events }\end{array}$ & & Meta-analysis & Metformin reduces cancer risk for $31 \%$ \\
\hline $\begin{array}{l}\text { Chang et al. [76], } \\
\text { Transl Oncol, } 2018\end{array}$ & CRC risk in T2DM & 47,597 & & Cohort study & $\begin{array}{l}\text { Metformin significantly reduced the risk } \\
\text { od CRC in dose-dependent manner }\end{array}$ \\
\hline $\begin{array}{l}\text { Zhang et al. [74], } \\
\text { J Clin Endocrinol Metab, } 2012\end{array}$ & Liver cancer risk in $\mathrm{T} 2 \mathrm{DM}$ & $\begin{array}{l}105,495 \text { cases } \\
\text { with T2DM }\end{array}$ & & Meta-analysis & $\begin{array}{l}\text { Metformin is associated with lower } \\
\text { risk of liver cancer in patients with } \\
\text { T2DM }\end{array}$ \\
\hline
\end{tabular}

Vitamin D and calcium

supplementation

Grau et al. [80],

J Natl Cancer Inst, 2003

$\begin{array}{lll}\text { Colorectal adenoma } & 803 & \text { RCT }\end{array}$

Calcium supplementation and vitamin $\mathrm{D}$ reduce the risk ofcolorectal adenoma recurremce

\begin{tabular}{|c|c|c|c|c|c|}
\hline $\begin{array}{l}\text { Wei et al. [81], } \\
\text { Cancer Epidemiol } \\
\text { Biomarkers Prev, } 2008\end{array}$ & Colorectal adenoma & 6,869 & 68,223 & Meta-analyses & $\begin{array}{l}\text { Both, circulating } 25(\mathrm{OH}) \mathrm{D} \text { and vitamin } \\
\text { D intake significant decreased risk of } \\
\text { colorectal adenoma incidence and } \\
\text { recurrence }\end{array}$ \\
\hline \multicolumn{6}{|l|}{ Statins } \\
\hline $\begin{array}{l}\text { Aggarwal et al. } \\
{[83], 2004}\end{array}$ & Cancer & & & Preclinical and clinical studies & $\begin{array}{l}\text { Resveratrol can be used for the } \\
\text { prevention and therapy of cancer }\end{array}$ \\
\hline $\begin{array}{l}\text { Chiu et al. [84], } \\
\text { Am J Gastroenterol, } 2011\end{array}$ & Gastric cancer & $\begin{array}{l}337 \text { gastric } \\
\text { cancer }\end{array}$ & 1,348 & $\begin{array}{l}\text { Population-based case-control } \\
\text { study }\end{array}$ & $\begin{array}{l}\text { Statins are associated with a reduced risk } \\
\text { of gastric cancer }\end{array}$ \\
\hline $\begin{array}{l}\text { Poynter et al. [86], } \\
\text { N Engl J Med, } 2005\end{array}$ & CRC & $1,953 \mathrm{CRC}$ & 2,015 & $\begin{array}{l}\text { Population-based case-control } \\
\text { study }\end{array}$ & $\begin{array}{l}\text { Statins are associated with a } 47 \% \text { relative } \\
\text { reduction risk of CRC }\end{array}$ \\
\hline
\end{tabular}


Table 1. (continued)

\begin{tabular}{|c|c|c|c|c|c|}
\hline Study & Treatment offered/cancer site & \multicolumn{2}{|c|}{ Number of cases/controls } & Design & Main results \\
\hline $\begin{array}{l}\text { Chiu et al. [85], } \\
\text { Am J Gastroenterol, } 2011\end{array}$ & Liver cancer & $\begin{array}{l}1,166 \text { liver } \\
\text { cancers }\end{array}$ & 1,166 & $\begin{array}{l}\text { Population-based case-control } \\
\text { study }\end{array}$ & $\begin{array}{l}\text { Statins may reduce the risk of liver } \\
\text { cancer }\end{array}$ \\
\hline \multicolumn{6}{|l|}{ Proton pump inhibitors } \\
\hline $\begin{array}{l}\text { Nguyen et al. [87], } \\
\text { Gastroenterol, } 2010\end{array}$ & Esophageal carcinoma & $\begin{array}{l}1,182 \text { Barret's } \\
\text { esophagus }\end{array}$ & 696 & $\begin{array}{l}\text { Observational case-control } \\
\text { cohort study }\end{array}$ & $\begin{array}{l}\text { PPI, NSAID/aspirin or statin therapy } \\
\text { might reduce the risk of esophageal } \\
\text { adenocarcinoma }\end{array}$ \\
\hline $\begin{array}{l}\text { Brusselaers et al. [88], } \\
\text { Cancer Epidemiol, } 2018\end{array}$ & Esophageal carcinoma & \multicolumn{2}{|l|}{796,492} & Population-based cohort study & $\begin{array}{l}\text { Long-term use of PPIs is associated with } \\
\text { increased risk of esophageal } \\
\text { adenocarcinoma }\end{array}$ \\
\hline $\begin{array}{l}\text { Brusselaers et al. [89], } \\
\text { BMJ Open, } 2017\end{array}$ & Gastric cancer & \multicolumn{2}{|l|}{797,067} & Population-based cohort study & $\begin{array}{l}\text { Long-term PPI use might be a risk factor } \\
\text { for gastric cancer }\end{array}$ \\
\hline $\begin{array}{l}\text { Cheung et al. [90], } \\
\text { Gut, } 2018\end{array}$ & Gastric cancer & \multicolumn{2}{|l|}{63,397} & Population-based cohort study & $\begin{array}{l}\text { Long-term PPIs was associated with an } \\
\text { increased risk for gastric cancer }\end{array}$ \\
\hline
\end{tabular}

RCT, randomised controlled trials; BDAT, British Doctors Aspirin Trial; UK-TIA, UK transient ischaemic attack trial; TPT, thrombosis prevention trial; SAPAT, Swedish Angina Pectoris Aspirin Trial; ETDRS, early treatment diabetic retinopathy study; JPAD, Japanese primary prevention of atherosclerosis with aspirin for diabetes; POPADAD, prevention of progression of arterial disease and diabetes; AAA, Aspirin for Asympptomatic Atherosclerosis; GI, gastrointestinal; CRC, colorectal carcinoma; FAP, familiar adenomatous polyposis; MALT, mucosa associated lymphoid tissue; T2DM, type 2 diabetes mellitus; PPI, proton pump inhibitors.

consumption of fruits, vegetables, and vitamins, there is still no conclusive evidence for the benefit for GI cancers or any type of cancer in humans overall $[24,25]$. However, modifying the dietary habit with food that has potential anti-inflammatory and anti-cancer characteristics like fish, poultry, fiber-rich diets, and unsaturated fats, has been commonly advocated $[13,14,15]$. Thus, future studies are needed to assess clinical benefits and harmful effects in humans.

\section{Chemoprevention}

Effective Preventive Treatments - Aspirin, NSAIDs, and COX-2 Selective Inhibitors

We have previously outlined in this article that there is substantial potential for primary prevention of CRC through modification of diet and lifestyle. Moreover, as many as $70 \%$ of the overall burden of CRC could be prevented through environmental changes. Among them, anti-inflammatory drugs such as aspirin, NSAIDs, and cyclooxygenase-2 (COX-2) selective inhibitors (COXIBs) are shown to be the most effective agents for GI cancer chemoprevention.

The first clinical study to investigate the chemopreventive effects of COXIBs was in high-risk patients with familial adenomatous polyposis, demonstrated reductions in the colorectal adenoma number of $28 \%$ with celecoxib at a dose of $400 \mathrm{mg}$ BID for 6 months [26]. After the trial, in 2000, the US Food and Drug Administration approved celecoxib as a new adjunctive treatment for patients with familial adenomatous polyposis [27]. Later on, Food and Drug Administration voluntarily withdrew ap- proval in 2011 due to challenges in confirmatory studies [28]. Thus, evidence from the studies in early 1990s and 2000s primarily demonstrated chemopreventive effects on colorectal adenoma. Subsequent randomised controlled trials and meta-analyses confirmed the beneficial effect of aspirin, non-aspirin NSAIDs, and COXIBs on the recurrence of adenomas [29]. However, associate adverse effects regarding bleeding, particularly for non-aspirin NSAIDs and COX-2, limited the potential for their use. Thus, further investigations have been focused on aspirin and they have found that the use of aspirin after diagnosis of CRC is associated with improved survival [30-32]. Moreover, it is well known that aspirin reduces the incidence of cardiovascular events by $12 \%$, both in the general population and in high-risk groups [33]. Thus, aspirin was one of the first pharmacologic agents recommended by the US Preventive Services Task Force for chemoprevention of a CRC primarily in adults aged $50-59$ years and possibly $60-69$ years, who have a $10 \%$ or greater 10-year risk for CVD [34, 35]. Later on, accumulating evidence supports an effect of aspirin in reducing CRC incidence and mortality not only in individuals with CVD risk but also in individuals with an average risk [36, 37].

There have been several proposed mechanisms by which aspirin, NSAIDs, and COXIBs reduce risk of CRC. It seems that the most convincing hypothesis is related to the ability of these agents to inhibit COX-2, a key enzyme that promotes inflammation and cell proliferation [3840]. COX-2 is a principal enzyme that produces proinflammatory prostaglandins, which increases cellular pro- 
liferation and resistance to apoptosis and promotes angiogenesis. Angiogenesis is an important role of COX-2 in CRC and is supported by several studies, showing that COX-2, but not COX-1 is progressively over expressed in colorectal adenomas and cancers in humans [41, 42]. Moreover, aspirin and NSAIDs have other potential antiinflammatory and anti-cancer mechanisms, including the inhibition of nuclear factor- $\kappa \mathrm{B}$, DNA repair, polyamines metabolism, Wnt signaling, activation of p38 kinase, and induction of apoptosis [43-47].

Although several observational studies and randomised trials provided compelling evidence that aspirin does reduce CRC when administered as daily doses of 300-1,200 mg, adverse effects like bleeding complications, limited its potential for long-term prevention. Thus, the key study that confirmed the effect of low dose aspirin on CRC incidence and mortality in individuals with average risk was published in 2010 [48]. This study analyzed 5 randomized trials with 14,033 participants and established the effect of aspirin on risk of CRC over 20 years. The most important finding was that the longterm use of low-dose aspirin reduced CRC mortality by $30 \%$ and CRC incidence by about $28 \%$. Moreover, the higher dose daily aspirin is shown to be as effective as 75 $\mathrm{mg}$, but has the greater risk of GI ulceration and bleeding complications. In addition, aspirin might have a greater effect on cancer of the proximal colon, reducing the incidence by about $70 \%$, but only about $5 \%$ in the rectum. Daily aspirin for at least 5 years reduced the risk of CRC after a latent period of about 7 years, while benefit increased with scheduled duration of treatment [48]. Another important meta-analysis investigated the effectiveness of aspirin versus screening for CRC and concluded that aspirin reduced CRC mortality by $19 \%$ compared to placebo [49]. Moreover, low-dose aspirin seems to be equally effective as flexible sigmoidoscopy or guiacfecal occult blood test screening to reduce CRC incidence and mortality, while low-dose aspirin was more effective for cancers in the proximal colon [49]. However, aspirin is not effective in all individuals with an average risk for CRC. This can be interpreted by the fact that CRC represents a complex disease resulting from a multiple interplay of genetic and epigenetic factors that are driving forces of cancerogenesis [50-52]. One of the fundamental concepts in tumorogenesis of CRC is "the adenoma-carcinoma sequence" that was proposed in the 1978 [53]. Although the concept "adenoma-carcinoma sequence" has never been proven directly, it affords a means of preventing CRC by endoscopic removal of precursor lesions. Moreover, this concept provides an excellent model to study the genesis of CRC. Since then, several genetic studies confirmed that the chromosomal instability pathway and microsatellite instability pathway are the 2 recognized pathways in tumorogenesis in CRC $[50,51]$. Thus, according to genetic variation, the use of aspirin and/or NSAIDs has been differentially associated with CRC risk. In the investigations that followed, regular aspirin use might be associated with a lower risk of BRAF-wild-type CRC [50]. Furthermore, genome-wide investigation of gene-environment interactions showed that 2 single nucleotide polymorphisms at chromosome 12 and 15 might modify the chemopreventive effect of aspirin or NSAIDs on CRC in some individuals [52].

It seems that the role of aspirin in primary prevention is not only limited to CRC, but also to other types of cancer, particularly of the GI tract. The first reliable evidence came from the study with 25,570 patients from 8 eligible trials, which investigated the 20 -year risk of death due to cancer [54]. This study demonstrated that long-term use of aspirin for 5-10 years would reduce the risk of death due to GI and non-GI solid cancers by about $20 \%$, while benefits increased with the scheduled duration of treatment. Effects were greatest for GI cancer, particularly CRC and esophageal cancers. Furthermore, 2 large prospective cohort studies included 88,084 women and 47,881 men, for 32 years of follow-up and confirmed that regular use of low-dose aspirin for at least 6 years was associated with a $1.8 \%$ lower risk for overall cancer, $8 \%$ for GIcancers overall, and $10.8 \%$ for CRC. However, this study did not observe the presence of a significant association between aspirin and breast, advanced prostate or lung cancer [55]. Another meta analysis showed an overall $29 \%$ reduced risk of gastric cancer corresponding to long-term aspirin use ( $\geq 4$ years) [56]. Thus far, the use of prophylactic aspirin for a minimum of 5 years at doses between 75 and $325 \mathrm{mg}$ appears to have a favorable benefit-harm profile, and might reduce the incidence of cancer by $7 \%$ in women and $9 \%$ in men (relative reduction dependent on age and sex). Longer use is likely to have greater benefits. The predominant adverse event caused by aspirin is GI bleeding, and there appears to be no valid evidence that the overall frequency of fatal GI bleeding is increased by daily low-dose aspirin $[36,57,58]$. On the other hand, recent populationbased study from the United Kingdom showed that lowdose aspirin was not associated with increased survival of patients diagnosed with esophageal or gastric cancer [59]. Thus, future studies would be of great interest to assess the exact effect of aspirin in the overall cancer incidence and mortality. 
Helicobacter Pylori Infection Eradication Strategy

According to epidemiological data, gastric cancer is the fifth most common newly diagnosed cancer and the third leading cause of cancer-related death worldwide [1]. It is well established that Helicobacter pylori (H. pylori) infection is the major etiological factor for gastric cancer. Approximately $89 \%$ of gastric cancers worldwide are associated with chronic $\mathrm{H}$. pylori infection [60, 61]. Moreover, localized stage gastric MALT lymphomas are strongly associated with $\mathrm{H}$. pylori infection [62]. According to this hypothesis, the International Agency for Research on Cancer of the World Health Organization (WHO) classified $\mathrm{H}$. pylori as a Group 1 carcinogen in 1994. Since then, important progress has been made in the management of $\mathrm{H}$. pylori. The $\mathrm{WHO}$ published the strategy plan that includes $\mathrm{H}$. pylori eradication, for preventing gastric cancer [63]. Furthermore, the working group in the Maastricht V/Florence Consensus reported that $\mathrm{H}$. pylori is an infectious disease, and should be treated, irrespective of an individual's symptoms or stage of disease [60]. To this end, eradication of $\mathrm{H}$. pylori and control of gastric inflammation induced by the pathogen are essential in the prevention of gastric cancer. Additionally, the risk of developing gastric cancer can be reduced more effectively by employing eradication treatment before the development of atrophy and intestinal metaplasia, which are 2 conditions considered preneoplastic lesions $[61,64]$. Thus, patients with gastric cancer usually have glandular atrophy and are at high risk for metachronous development of new gastric cancer. Thus the long-term effects of $\mathrm{H}$. pylori eradication in this particular group of patients might prevent the development of metachronous gastric cancer [65].

\section{Vaccination and Antiviral Therapy}

Primary liver cancer is the fifth most common cancer and the second leading cause of cancer-related death, accounting for $7 \%$ of all cancers worldwide [66]. Hepatocellular carcinoma (HCC) represents about $90 \%$ of primary liver cancers, and the incidence of HCC is increasing globally, this being among one of the leading causes of cancer death in the world. Cirrhosis is an important risk factor for HCC, and may be caused by chronic viral hepatitis $\mathrm{B}(\mathrm{HBV})$ and $\mathrm{C}$, alcohol consumption, aflatoxin, and inherited metabolic diseases, such as non-alcohol fatty liver disease or genetic hemochromatosis. Overall, one third of cirrhotic patients will develop HCC, but the risk is higher in patients with chronic viral HBV and hepatitis C (HCV) [67]. Thus, the main goal of therapy for $\mathrm{HBV}$ and $\mathrm{HCV}$ infection is reduction of infection globally, and consequently prevention of disease progression and HCC development [67-69]. Currently, HBV infection can be prevented by available safe and effective vaccine. Vaccination against $\mathrm{HBV}$ reduces the risk of HCC and is recommended for newborns and high-risk groups [68]. On the other hand, in individuals with infection, antiviral therapy for chronic $\mathrm{HBV}$ and $\mathrm{HCV}$ is beneficial in preventing progression, although does not eliminate the risk of HCC development. Antiviral therapies should follow the EASL guidelines and WHO targets for management of chronic HBV and HCV infection [68-70].

\section{Metformin, Vitamin D, Statins, and Proton}

Pump Inhibitors

Several other agents including metformin, vitamin D, statins and proton pump inhibitors (PPIs) might have chemopreventive effects based on findings from several population-based observational studies. Thus, previous studies have shown an association between the longterm administration of metformin among patients with diabetes, and lower risks of cancer and cancer mortality, in general $[71,72]$. Later on, a few meta-analyses have demonstrated the chemopreventive effect of metformin for cancer overall, particularly for liver cancer and among patients with type 2 diabetes mellitus (T2DM) $[73,74]$. Thus, a $31 \%$ reduction in overall relative cancer risk was found in individuals taking metformin compared with other antidiabetic drugs, particularly for HCC and pancreatic cancer, while nonsignificant for breast, colon, and prostate cancer [73]. Moreover, metformin treatment seems to be associated with a lower risk for esophageal and gastric cancer [71]. Besides, the growing body of evidence suggests that patients with T2DM have an increased risk of CRC [75]. In addition, both CRC and T2DM share some of the same risk factors such as dietary habit, obesity, and physical inactivity. Yet, the national Taiwan cohort study that included 47,597 T2DM patients revealed that metformin use significantly reduces the risk of CRC in a dose-dependent manner [76].

A first studies with positive effect of vitamin D on CRC risk in rats was proposed more than 25 years ago [77]. Later on, many experimental studies and epidemiological investigations have shown that vitamin D can have an antineoplastic effect, inhibiting cell proliferation and promoting apoptosis $[78,79]$. One of the key studies that included 803 individuals in the randomized, placebo-controlled, multi-center clinical trial in 2003 provided a strong indication that vitamin $\mathrm{D}$ and calcium have a joint 
antineoplastic effect in the colon, reducing the risk of colorectal adenoma recurrence [80]. Nevertheless, further data and meta-analyses clearly suggest the potential for important chemopreventive effects of vitamin D and colorectal adenoma [81, 82].

On the other hand, large randomized controlled trials investigated the effects of statins to prevent CVD and to safety reasons analyzed whether statins increased cancer incidence and cancer mortality, and surprisingly showed that statins can actually prevent cancer. Consequently, observational studies and meta-analyses have shown that long-term statin use significantly reduces the incidence of GI cancer, particularly gastric cancer and CRC [83-86]. Furthermore, there is some evidence that statins might be useful in the prevention of liver cancer [85]. However, the beneficial effects of statins on inhibiting carcinogenesis should be clarified by ongoing and future studies within large prospective cohorts.

It is well known that PPIs are the most important pharmacological agents in the management of patients with Barrett's esophagus as they control symptoms, heal ulcerations, and prevent strictures. Moreover, observational studies demonstrated that PPIs effectively reduced the progression of non-dysplastic Barrett's esophagus to esophageal adenocarcinoma [87]. On the other hand, the population-based cohort study on 796,492 patients on long-term therapy with PPIs showed increased risk of esophageal adenocarcinoma [88]. It is well known that PPIs induced hypergastrinemia, while the patients with high gastrin values had increased risk of gastric cancer. Although there is some evidence for increased risk of gastric cancer in patients treated on long-term PPI after $\mathrm{H}$. pylori eradication, the association between chronic PPI use and both gastric cancer and esophageal cancer risk is still controversial [87-90]. However, additional studies are warranted to establish the potential of metformin, vitamin D, statins, and PPIs in the chemoprevention of cancer overall.

\section{Conclusion}

Despite the developments in genetic studies, novel treatment approaches, and progressive interest in chemoprevention in the last several decades, GI cancers remain a source of considerable morbidity and mortality all over the world. As a result of past investments, current therapeutic GI cancer prevention include the integration of various activities such as lifestyle changes to reduce risk, vaccines, screening to detect early lesions and preventive therapies aimed to actively interrupt the carcinogenic pathway. Long-term aspirin use seems to have the largest potential effect on the general population on cancer incidence and mortality overall. Aspirin taken for several years at doses of at least $75 \mathrm{mg}$ daily, reduces long-term cancer incidence for $7-10 \%$, overall, and appears to have a favorable benefit-harm profile. Moreover, aspirin is likely to have the greatest benefits for 3 common GI cancers: colon, gastric, and esophageal. $\mathrm{H}$. pylori eradication reduces the risk for gastric cancer and is advocated, regardless of the symptoms and stage of disease. Metformin and statins are promising in cancer prevention in patients with T2DM. Numerous studies have shown that vitamin $\mathrm{D}$ intake is associated with a reduced risk of colorectal adenoma. In the future, the chemoprevention in digestive oncology will focus on better identification and individualize decision making to the specific patient in order to have great efficacy with fewer and tolerable risks. Thus, further studies with large prospective cohorts are warranted to establish the potential of various agents and to identify more specific and highly targeted new agents for the chemoprevention of cancer overall.

\section{Acknowledgment}

All authors contributed equally to this article.

\section{Ethics Statement}

The authors declare that they have no ethical conflicts to disclose.

\section{Disclosure Statement}

The authors declare that they have no conflicts of interest to disclose.

\section{Funding Sources}

The authors received no specific funding for this work.

\section{Authors Contribution}

M.N.K.: conceptualization. M.N.K. and T.M.: supervision. M.N.K., D.D.M., D.D.P., and A.P.M.: writing original draft. M.N.K., D.D.M., and T.M.: writing \pm review and editing. 


\section{References}

1 Fitzmaurice C, Allen C, Barber RM, Barregard L, Bhutta ZA, Brenner H, et al.; Global Burden of Disease Cancer Collaboration. Global, regional, and national cancer incidence, mortality, years of life lost, years lived with disability, and disability-adjusted lifeyears for 32 Cancer Groups, 1990 to 2015. A systematic analysis for the Global Burden of Disease Study. JAMA Oncol. 2017 Apr 1;3(4): 524-548.

2 Forouzanfar MH, Afshin A, Alexander LT, Anderson HR, Bhutta ZA, Biryukov S, et al.; GBD 2015 Risk Factors Collaborators. Global, regional, and national comparative risk assessment of 79 behavioural, environmental and occupational, and metabolic risks or clusters of risks, 1990-2015: a systematic analysis for the Global Burden of Disease Study 2015. Lancet. 2016 Oct;388(10053):1659-724.

3 Peery AF, Crockett SD, Barritt AS, Dellon ES, Eluri S, Gangarosa LM, Jensen ET, Lund JL, Pasricha S,Runge T, Schmidt M, Shaheen NJ, Sandler RS. Burden of gastrointestinal, liver, and pancreatic diseases in the United States. Gastroenterology. 2015 Dec;149(7): 1731-1741.e3.

4 National Cancer Institute. Surveillance, Epidemiology, and End Results program (SEER) Cancer Statistics Review (CSR) 1975-2015 [cited 2018 April 16].

5 Sporn MB. Approaches to prevention of epithelial cancer during the preneoplastic period. Cancer Res. 1976 Jul;36(7 PT 2):2699702.

6 Chun KS, Kim EH, Lee S, Hahm KB. Chemoprevention of gastrointestinal cancer: the reality and the dream. Gut Liver. 2013 Mar;7(2): 137-49.

7 Bisgaard ML, Fenger K, Bülow S, Niebuhr E, Mohr J. Familial adenomatous polyposis (FAP): frequency, penetrance, and mutation rate. Hum Mutat. 1994;3(2):121-5.

8 Guillem JG, Wood WC, Moley JF, Berchuck A, Karlan BY, Mutch DG, et al.; ASCO; SSO. ASCO/SSO review of current role of risk-reducing surgery in common hereditary cancer syndromes. J Clin Oncol. 2006 Oct;24(28): 4642-60.

9 Chang MH, You SL, Chen CJ, Liu CJ, Lai MW, Wu TC, et al.; Taiwan Hepatoma Study Group. Long-term effects of hepatitis B immunization of infants in preventing liver cancer. Gastroenterology. 2016 Sep;151(3):472480.e1.

10 Cuzick J. Preventive therapy for cancer. Lancet Oncol. 2017;18:e472-82.

11 American Cancer Society. Cancer facts and figures 2018. Atlanta: American Cancer Society 2018. https://doi.org/10.1016/S14702045(17)30536-3.

12 Calle EE, Rodriguez C, Walker-Thurmond K, Thun MJ. Overweight, obesity, and mortality from cancer in a prospectively studied cohort of U.S. adults. N Engl J Med. 2003 Apr; 348(17):1625-38.
13 Trock B, Lanza E, Greenwald P. Dietary fiber, vegetables, and colon cancer: critical review and meta-analyses of the epidemiologic evidence. J Natl Cancer Inst. 1990 Apr;82(8): 650-61.

14 Park Y, Hunter DJ, Spiegelman D, Bergkvist L, Berrino F, van den Brandt PA, et al. Dietary fiber intake and risk of colorectal cancer: a pooled analysis of prospective cohort studies. JAMA. 2005 Dec;294(22):2849-57.

15 Gaard M, Tretli S, Løken EB. Dietary factors and risk of colon cancer: a prospective study of 50,535 young Norwegian men and women. Eur J Cancer Prev. 1996 Dec;5(6):445-54.

16 Norat T, Bingham S, Ferrari P, Slimani N, Jenab M, Mazuir M, et al. Meat, fish, and colorectal cancer risk: the European Prospective Investigation into cancer and nutrition. J Natl Cancer Inst. 2005 Jun;97(12):906-16.

17 Gerhardsson de Verdier M, Hagman U, Peters RK, Steineck G, Overvik E. Meat, cooking methods and colorectal cancer: a case-referent study in Stockholm. Int J Cancer. 1991 Oct;49(4):520-5.

18 Keum NN, Bao Y, Smith-Warner SA, Orav J, Wu K, Fuchs CS, Giovannucci EL. Association of physical activity by type and intensity with digestive system cancer risk. JAMA Oncol. 2016 Sep 1;2(9):1146-53.

19 Wang XQ, Terry PD, Yan H. Review of salt consumption and stomach cancer risk: epidemiological and biological evidence. World J Gastroenterol. 2009 May;15(18):2204-13.

20 Chan AT, Giovannucci EL. Primary prevention of colorectal cancer. Gastroenterology. 2010 Jun;138(6):2029-2043.e10.

21 Friedenreich CM, Orenstein MR. Physical activity and cancer prevention: etiologic evidence and biological mechanisms. J Nutr. 2002 Nov;132(11 Suppl):3456S-64S.

22 World Cancer Research Fund/American In stitute for Cancer Research. Continuous update project report. Food, nutrition, physical activity, and the prevention of colorectal cancer. [cited 2015 Sept 13]. Available from: http://wcrf.org/.

23 Samad AK, Taylor RS, Marshall T, Chapman MA. A meta-analysis of the association of physical activity with reduced risk of colorectal cancer. Colorectal Dis. 2005 May;7(3): 204-13.

24 Bjelakovic G, Gluud LL, Nikolova D, Whitfield K, Krstic G, Wetterslev J, et al. Vitamin $\mathrm{D}$ supplementation for prevention of cancer in adults. Cochrane Database Syst Rev. 2014 Jun;6(6):CD007469.

25 Bjelakovic G, Nikolova D, Gluud LL, Simonetti RG, Gluud C. Mortality in randomized trials of antioxidant supplements for primary and secondary prevention: systematic review and meta-analysis. JAMA. 2007 Feb;297(8): 842-57.

26 Steinbach G, Lynch PM, Phillips RK, Wallace $\mathrm{MH}$, Hawk E, Gordon GB, et al. The effect of celecoxib, a cyclooxygenase- 2 inhibitor, in fa- milial adenomatous polyposis. N Engl J Med. 2000 Jun;342(26):1946-52.

27 Henney JE. Celecoxib indicated for FAP. JAMA. 2000;283(9):1131.

28 Food and drug administration. Withdrawal of approval of familial adenomatous polyposis (FAP) indication for Celebrix (Pfizer, Inc.) Fed Regist. 2012;34052.

29 Veettil SK, Lim KG, Ching SM, Saokaew S, Phisalprapa P, Chaiyakunapruk N. Effects of aspirin and non-aspirin nonsteroidal anti-inflammatory drugs on the incidence of recurrent colorectal adenomas: a systematic review with meta-analysis and trial sequential analysis of randomized clinical trials. BMC Cancer. 2017 Nov; 17(1):763.

30 Baron JA, Cole BF, Sandler RS, Haile RW, Ahnen D, Bresalier R, et al. A randomized trial of aspirin to prevent colorectal adenomas. N Engl J Med. 2003 Mar;348(10):891-9.

31 Benamouzig R, Deyra J, Martin A, Girard B, Jullian E, Piednoir B, et al. Daily soluble aspirin and prevention of colorectal adenoma recurrence: one-year results of the APACC trial. Gastroenterology. 2003 Aug;125(2):328-36.

32 Sandler RS, Halabi S, Baron JA, Budinger S, Paskett E, Keresztes R, et al. A randomized trial of aspirin to prevent colorectal adenomas in patients with previous colorectal cancer. $\mathrm{N}$ Engl J Med. 2003 Mar;348(10):883-90.

33 Antithrombotic Trialists' (ATT) Collaboration. Baigent C, Blackwell L, Collins R, Emberson J, Godwin J, Peto R, Buring J, Hennekens C, Kearney P, Meade T, Patrono C, Roncaglioni MC, Zanchetti A. Aspirin in the primary and secondary prevention of vascular disease: collaborative meta-analysis of individual participant data from randomised trials. Lancet. 2009 May 30; 373(9678):1849-60.

34 Dehmer SP, Maciosek MV, Flottemesch TJ, LaFrance AB, Whitlock EP. Aspirin for the primary prevention of cardiovascular disease and colorectal cancer: a decision analysis for the U.S. Preventive Services Task Force. Ann Intern Med. 2016 Jun;164(12):777-86.

35 Bibbins-Domingo K; U.S. Preventive Services Task Force. Aspirin use for the primary prevention of cardiovascular disease and colorectal cancer: U.S. Preventive Services Task Force Recommendation Statement. Ann Intern Med. 2016 Jun;164(12):836-45.

36 Chan AT, Ladabaum U. Where do we stand with aspirin for the prevention of colorectal cancer? The USPSTF recommendations. Gastroenterology. 2016 Jan;150(1):14-8.

37 Flossmann E, Rothwell PM; British Doctors Aspirin Trial and the UK-TIA Aspirin Trial. Effect of aspirin on long-term risk of colorectal cancer: consistent evidence from randomised and observational studies. Lancet. 2007 May;369(9573):1603-13.

38 Chan AT. COX-2 expression in adenoma: an imperfect marker for chemoprevention. Gut. 2010 May;59(5):568-9. 
39 Benamouzig R, Uzzan B, Martin A, Deyra J, Little J, Girard B, et al.; APACC Study Group. Cyclooxygenase- 2 expression and recurrence of colorectal adenomas: effect of aspirin chemoprevention. Gut. 2010 May;59(5):622-9.

40 Dubois RN. Review article: cyclooxygenasea target for colon cancer prevention. Aliment Pharmacol Ther. 2000 Apr;14 Suppl 1:64-7.

41 Eberhart CE, Coffey RJ, Radhika A, Giardiello FM, Ferrenbach S, DuBois RN. Up-regulation of cyclooxygenase 2 gene expression in human colorectal adenomas and adenocarcinomas. Gastroenterology. 1994 Oct;107(4): $1183-8$

42 Ogino S, Chan AT, Fuchs CS, Giovannucci E Molecular pathological epidemiology of colorectal neoplasia: an emerging transdisciplinary and interdisciplinary field. Gut. 2011 Mar;60(3):397-411.

43 Kopp E, Ghosh S. Inhibition of NF-kappa B by sodium salicylate and aspirin. Science. 1994 Aug;265(5174):956-9.

44 Schwenger P, Bellosta P, Vietor I, Basilico C, Skolnik EY, Vilcek J. Sodium salicylate induces apoptosis via p38 mitogen-activated protein kinase but inhibits tumor necrosis factorinduced c-Jun N-terminal kinase/stress-activated protein kinase activation. Proc Natl Acad Sci USA. 1997 Apr;94(7):2869-73.

45 Martinez ME, O'Brien TG, Fultz KE, Babbar $\mathrm{N}$, Yerushalmi H, Qu N, et al. Pronounced reduction in adenoma recurrence associated with aspirin use and a polymorphism in the ornithine decarboxylase gene. Proc Natl Acad Sci USA. 2003 Jun;100(13):7859-64.

46 Gala MK, Chan AT. Molecular pathways: aspirin and Wnt signaling-a molecularly targeted approach to cancer prevention and treatment. Clin Cancer Res. 2015 Apr;21(7):1543-8.

47 Drew DA, Cao Y, Chan AT. Aspirin and colorectal cancer: the promise of precision chemoprevention. Nat Rev Cancer. 2016 Mar; 16(3):173-86

48 Rothwell PM, Wilson M, Elwin CE, Norrving $B$, Algra A, Warlow CP, et al. Long-term effect of aspirin on colorectal cancer incidence and mortality: 20-year follow-up of five randomised trials. Lancet. 2010 Nov;376(9754): 1741-50.

49 Emilsson L, Holme $\varnothing$, Bretthauer M, Cook NR, Buring JE, Løberg M, et al. Systematic review with meta-analysis: the comparative effectiveness of aspirin vs. screening for colorectal cancer prevention. Aliment Pharmacol Ther. 2017 Jan;45(2):193-204.

50 Nishihara R, Lochhead P, Kuchiba A, Jung S, Yamauchi M, Liao X, et al. Aspirin use and risk of colorectal cancer according to BRAF mutation status. JAMA. 2013 Jun;309(24): 2563-71.

51 Armaghany T, Wilson JD, Chu Q, Mills G. Genetic alterations in colorectal cancer. Gastrointest Cancer Res. 2012 Jan;5(1):19-27.

52 Nan H, Hutter CM, Lin Y, Jacobs EJ, Ulrich CM, White E, et al.; CCFR; GECCO. Association of aspirin and NSAID use with risk of colorectal cancer according to genetic variants. JAMA. 2015 Mar;313(11): 1133-42.

53 Hill MJ, Morson BC, Bussey HJ. Aetiology of adenoma-carcinoma sequence in large bowel. Lancet. 1978 Feb;1(8058):245-7.

54 Rothwell PM, Fowkes FG, Belch JF, Ogawa H, Warlow CP, Meade TW. Effect of daily aspirin on long-term risk of death due to cancer: analysis of individual patient data from randomised trials. Lancet. 2011 Jan;377(9759): 31-41.

55 Cao Y, Nishihara R, Wu K, Wang M, Ogino S, Willett WC, et al. Population-wide impact of long-term use of aspirin and the risk for cancer. JAMA Oncol. 2016 Jun;2(6): $762-9$.

56 Ye X, Fu J, Yang Y, Gao Y, Liu L, Chen S. Frequency-risk and duration-risk relationships between aspirin use and gastric cancer: a systematic review and meta-analysis. PLoS One. 2013 Jul;8(7):e71522.

57 Cuzick J, Thorat MA, Bosetti C, Brown PH, Burn J, Cook NR, et al. Estimates of benefits and harms of prophylactic use of aspirin in the general population. Ann Oncol. 2015 Jan; 26(1):47-57.

58 Elwood PC, Morgan G, Galante J, Chia JW, Dolwani S, Graziano JM, et al. Systematic review and meta-analysis of randomised trials to ascertain fatal gastrointestinal bleeding events attributable to preventive low-dose aspirin: no evidence of increased risk. PLoS One. 2016 Nov;11(11): e0166166.

59 Spence AD, Busby J, Johnston BT, Baron JA, Hughes CM, Coleman HG, et al. Low-dose aspirin use does not increase survival in 2 independent population-based cohorts of patients with esophageal or gastric cancer. Gastroenterology. 2018 Mar;154(4):849-860.e1.

60 Malfertheiner P, Megraud F, O'Morain CA, Gisbert JP, Kuipers EJ, Axon AT, et al. European Helicobacter and Microbiota Study Group and Consensus panel. Management of Helicobacter pylori infection-the Maastricht V/Florence Consensus Report. Gut. 2017 Jan; 66(1):6-30

61 Song H, Ekheden IG, Zheng Z, Ericsson J, Nyrén $\mathrm{O}, \mathrm{Ye} \mathrm{W}$. Incidence of gastric cancer among patients with gastric precancerous lesions: observational cohort study in a low risk Western population. BMJ. 2015 Jul;351: h3867.

62 Nakamura S, Sugiyama T, Matsumoto T, Iijima K, Ono S, Tajika M, et al.; JAPAN GAST Study Group. Long-term clinical outcome of gastric MALT lymphoma after eradication of Helicobacter pylori: a multicentre cohort follow-up study of 420 patients in Japan. Gut. 2012 Apr;61(4):507-13.

63 IARC Working Group Reports. Helicobacter pylori eradication as a strategy for preventing gastric cancer. World Health Organization. 2014:8.

64 Ford AC, Forman D, Hunt RH, Yuan Y, Moayyedi P. Helicobavter pylori eradication therapy to prevent gastric cancer in healthy asymptomatic infected individuals: systematic review and meta-analysis of randomised controlled trials. BMJ. 2014;348:g3174.

65 Choi IJ, Kook MC, Kim YI, Cho SJ, Lee JY, Kim CG, et al. Helicobacter pylori therapy for the prevention of metachronous gastric cancer. N Engl J Med. 2018 Mar;378(12):108595.

66 Akinyemiju T, Abera S, Ahmed M, Alam N, Alemayohu MA, Allen C, et al.; Global Burden of Disease Liver Cancer Collaboration. The burden of primary liver cancer and underlying etiologies from 1990 to 2015 at the global, regional, and national level. JAMA Oncol. 2017 Dec;3(12):1683-91.

67 Galle PR, Forner A, Llovet JM, Mazzaferro V, Piscaglia F, Raoul JL, et al.; European Association for the Study of the Liver. Electronic address: easloffice@easloffice.eu; European Association for the Study of the Liver. European Association for the Study of the liver. EASL Clinical Practice Guidelines: management of hepatocellular carcinoma. J Hepatol. 2018 Jul;69(1):182-236.

68 European Association for the Study of the liver. EASL Clinical Practice Guidelines on the management of hepatitis B virus infection. J Hepatol. 2017 Aug;67(2):370-398.

69 Pawlotsky JM, Negro F, Aghemo A, Berenguer M, Dalgard O, Dusheiko G, et al.; European Association for the Study of the Liver. Electronic address: easloffice@easloffice.eu; European Association for the Study of the Liver. European Association for the Study of the liver. EASL Recommendations of treatment of hepatitis C 2018. J Hepatol. 2018 Aug; 69(2):461-511.

70 European Union HCV Collaborators. Hepatitis $\mathrm{C}$ virus prevalence and level of intervention required to achive the WHO targets for elimination of intervention required to achieve the WHO targets for elimination in the European Union by 2030: a modelling study. Lancet Gastroenterol Hepatol. 2017;2:325-36.

71 Evans JM, Donnelly LA, Emslie-Smith AM, Alessi DR, Morris AD. Metformin and reduced risk of cancer in diabetic patients. BMJ. 2005 Jun;330(7503):1304-5.

72 Currie CJ, Poole CD, Gale EA. The influence of glucose-lowering therapies on cancer risk in type 2 diabetes. Diabetologia. 2009 Sep; 52(9):1766-77.

73 Decensi A, Puntoni M, Goodwin P, Cazzaniga M, Gennari A, Bonanni B, et al. Metformin and cancer risk in diabetic patients: a systematic review and meta-analysis. Cancer Prev Res (Phila). 2010 Nov;3(11):1451-61.

74 Zhang ZJ, Zheng ZJ, Shi R, Su Q, Jiang Q, Kip KE. Metformin for liver cancer prevention in patients with type 2 diabetes: a systematic review and meta-analysis. J Clin Endocrinol Metab. 2012 Jul;97(7):2347-53.

75 Yuhara H, Steinmaus C, Cohen SE, Corley DA, Tei Y, Buffler PA. Is diabetes mellitus an independent risk factor for colon cancer and rectal cancer? Am J Gastroenterol. 2011 Nov; 106(11):1911-21. 
76 Chang YT, Tsai HL, Kung YT, Yeh YS, Huang $\mathrm{CW}, \mathrm{Ma} \mathrm{CJ}$, et al. Dose-dependent relationship between metformin and colorectal cancer occurrence among patients with type 2 diabetes-a Nationwide cohort study. Transl Oncol. 2018 Apr;11(2):535-41.

77 Beaty MM, Lee EY, Glauert HP. Influence of dietary calcium and vitamin D on colon epithelial cell proliferation and 1,2-dimethylhydrazine-induced colon carcinogenesis in rats fed high fat diets. J Nutr. 1993 Jan;123(1): 144-52.

78 Díaz GD, Paraskeva C, Thomas MG, Binderup L, Hague A. Apoptosis is induced by the active metabolite of vitamin D3 and its analogue EB1089 in colorectal adenoma and carcinoma cells: possible implications for prevention and therapy. Cancer Res. $2000 \mathrm{Apr}$; 60(8):2304-12.

79 Fleet JC, DeSmet M, Johnson R, Li Y. Vitamin $\mathrm{D}$ and cancer: a review of molecular mechanisms. Biochem J. 2012 Jan;441(1):61-76.

80 Grau MV, Baron JA, Sandler RS, HaileRW, BeachML, ChurchTR, Heber D. Vitamin D, calcium supplementation, and colorectal ad- enomas: results of a randomized trial. J Natl Cancer Inst. 2003 Dec 3;95(23):1765-71

81 Wei MY, Garland CF, Gorham ED, Mohr SB, Giovannucci E. Vitamin D and prevention of colorectal adenoma: a meta-analysis. Cancer Epidemiol Biomarkers Prev. 2008 Nov; 17(11):2958-69.

82 Garland CF, Garland FC, Gorham ED, Lipkin M, Newmark H, Mohr SB, et al. The role of vitamin $\mathrm{D}$ in cancer prevention. Am J Public Health. 2006 Feb;96(2):252-61.

83 Aggarwal BB, Bhardwaj A, Aggarwal RS, Seeram NP, Shishodia S, Takada Y. Role of resveratrol in prevention and therapy of cancer: preclinical and clinical studies. Anticancer Res. 2004 Sep-Oct;24 5A:2783-840.

84 Chiu HF, Ho SC, Chang CC, Wu TN, Yang CY. Statins are associated with a reduced risk of gastric cancer: a population-based casecontrol study. Am J Gastroenterol. 2011 Dec; 106(12):2098-103.

85 Chiu HF, Ho SC, Chen CC, Yang CY. Statin use and the risk of liver cancer: a populationbased case-control study. Am J Gastroenterol. 2011 May;106(5):894-8.
86 Poynter JN, Gruber SB, Higgins PD, Almog R, Bonner JD, Rennert HS, et al. Statins and the risk of colorectal cancer. N Engl J Med. 2005 May;352(21):2184-92.

87 Nguyen DM, Richardson P, El-Serag HB. Medications (NSAIDs, statins, proton pump inhibitors) and the risk of esophageal adenocarcinoma in patients with Barrett's esophagus. Gastroenterology. 2010 Jun; 138(7):2260-6

88 Brusselaers N, Engstrand L, Lagergren J. Maintenance proton pump inhibition therapy and risk of oesophageal cancer. Cancer Epidemiol. 2018 Apr;53:172-7.

89 Brusselaers N, Wahlin K, Engstrand L, Lagergren J. Maintenance therapy with proton pump inhibitors and risk of gastric cancer: a nationwide population-based cohort study in Sweden. BMJ Open. 2017 Oct; 7(10):e017739.

90 Cheung KS, Chan EW, Wong AY, Chen L, Wong IC, Leung WK. Long-term proton pump inhibitors and risk of gastric cancer development after treatment for Helicobacter pylori: a population-based study. Gut. 2018 Jan;67(1):28-35. 